\title{
Influence of Mechanical Surface Preparation Methods on the Bonding of Southern Pine and Spotted Gum: Tensile Shear Strength of Lap Joints
}

\author{
William Leggate,,${ }^{\mathrm{a}, \mathrm{b}, *}$ Robert L. McGavin, ${ }^{\mathrm{b}}$ Andrew Outhwaite, ${ }^{\mathrm{b}}$ Chandan Kumar, ${ }^{\mathrm{b}}$ Adam \\ Faircloth, ${ }^{\mathrm{b}}$ and Mark Knackstedt ${ }^{\mathrm{a}}$
}

\begin{abstract}
Southern pine and spotted gum are two of Australia's most important locally produced commercial timbers. However, internationally, they are amongst the most problematic species to glue cost-effectively, especially for sawn-laminate-based structural engineered wood products, such as glulam and cross-laminated timber. This study investigated the efficacy of different pre-gluing wood surface machining preparations on the tensile shear strength of lap shear samples prepared from both species. Surface machining methods tested included planing, face milling, and sanding post-planing with 40 and 80 grit sandpaper. Wood face milling is not currently used commercially in Australia and has not previously been adequately tested on Australian commercial timbers to improve wood adhesion. Planing is currently the most common method used internationally for preparing wood surfaces for gluing. For both species, face milling with fast feed speed $(45 \mathrm{~m} / \mathrm{min})$, slow cutter speed $(57 \mathrm{~m} / \mathrm{s})$, and sanding treatments post-planing resulted in significantly higher tensile shear strength compared to planing for lap shear samples that had been subjected to an accelerated weathering process. Performance differences in tensile shear strength between surface machining methods are likely to be related to the effects of these machining methods on surface roughness, fibrillation, and sub-surface cell damage.
\end{abstract}

Keywords: Wood machining; Wood adhesion; Face milling; Tensile shear strength; Lap shear;

Pinus elliottii; Pinus caribaea; Corymbia citriodora

Contact information: a: Research School of Physics and Engineering, The Australian National University, Canberra, ACT 0200, Australia; b: Queensland Department of Agriculture and Fisheries, Horticulture and Forestry Science, Salisbury Research Facility, 50 Evans Rd, Salisbury, Qld 4107, Australia

*Corresponding author: william.leggate@daf.qld.gov.au

\section{INTRODUCTION}

Due to changes in forest resource quality, availability, product manufacturing advancements, and market demands, engineered wood products (EWPs) are a rapidly growing market share for both structural and appearance end-uses (Leggate 2018; Leggate et al. 2020; Market Research Future 2020). Most EWPs contain adhesives as the key binding material that joins the wood components together. For some important Australian commercial timbers, such as southern pine (Pinus elliottii (PEE), Pinus caribaea $(\mathrm{PCH})$, PEE $\times$ PCH: the hybrid between these two species) and spotted gum (Corymbia citriodora), effective wood adhesion is a major technical and commercial obstacle to overcome, particularly in the production of sawn-laminate-based structural EWPs, such as glued laminated timber (glulam) and cross-laminated timber (CLT). 
The technical challenges encountered in gluing these species have been attributed to their high density and differences in wood chemistry relative to many other commercial timbers that are easier to glue (Leggate et al. 2020). For southern pine, problems with wood adhesion are worse for higher-density wood such as that typical of higher stiffness grades more frequently targeted for structural glulam manufacture (Leggate et al. 2020).

Mechanical surface machining is a standard international timber industry practice used to size and prepare the wood laminates prior to gluing (Leggate et al. 2020). The most popular method used is planing of the wood surface immediately before gluing (Knorz et al. 2015). Surface machining prior to adhesive application has been shown to improve wood adhesion by increasing the wettability of the wood surface and improving adhesive penetration and bonding by: 1) activating the wood surface through the removal of extractives (which have migrated to the surface) and contaminants (e.g., dust and dirt); 2) creating micro-cracks and exposing wood cell lumens; 3 ) rupturing the molecular bonds between wood components and thereby creating open bonds, which increases the number of active sites for the adhesive polar groups to bond to; 4) creating a flat surface allowing for a close fit between the two wood adherends; and 5) increasing the number of mechanical interlocking sites for the adhesive to bond with the wood (Vick 1999; Sernek 2002; Aydin 2004; Leggate et al. 2020; Vella 2020).

Limited international studies have compared the benefits for wood adhesion after different mechanical surface preparation methods such as planing, sanding, face milling, and more recently scarification or incising (Hernández and Cool 2008a,b; Kläusler et al. 2014; Knorz et al. 2015; Vella et al. 2019a; Leggate et al. 2020; Vella 2020). Several studies have generally shown face milling to be more successful in improving the bond performance of timbers compared to planing and sanding, although results vary depending on adhesive type and timber species (Kläusler et al. 2014; Knorz et al. 2015; Leggate et al. 2020; Vella 2020). However, these previous studies focused mainly on European and North American species and were limited in the range of machining configurations trialed for each surface preparation method. Additionally, wood face milling is not currently used commercially in Australia and it has not yet been adequately tested on Australian timbers to improve wood adhesion (Leggate et al. 2020).

This study forms part of a series of experiments investigating the effects of different wood surface machining methods on wood adhesion for major Australian commercial timbers. The previous study detailed the impact of different mechanical surface preparation techniques on the wettability and permeability of southern pine and spotted gum (Leggate et al. 2020). The key conclusion from that study was that compared to other surface machining methods, conventional planing produced the lowest surface wettability for both southern pine and spotted gum. Improved wettability was achieved using face milling and sanding treatments post-planing. For spotted gum, planing produced the lowest permeability, whereas for southern pine, in an opposite trend to the wettability results, planing achieved the highest permeability. While providing new and important information, the scope of the previous study did not allow a direct connection between the observed differences with wettability and permeability, with demonstrated adhesive performance. This study extends the previous work and investigates the influence of different surface machining preparations on the tensile shear strength of southern pine and spotted gum glued wood joints. 


\section{EXPERIMENTAL}

\section{Wood Material}

The species used in this study were southern pine (Pinus elliottii (PEE), Pinus caribaea $(\mathrm{PCH}), \mathrm{PEE} \times \mathrm{PCH}$ : the hybrid between these two species) from Queensland's industrial plantations, and native forest grown spotted gum (Corymbia citriodora). These species represent the dominant commercial softwood and hardwood timber species processed by the Queensland forest products industry. The difficulties in gluing southern pine increase with higher density wood. Therefore, targeting machine graded pine, MGP15 (in accordance with Australian and New Zealand Standard AS/NZS 1748.1 (2011) and Australian Standard AS 1720.2 (2006) ensured that higher density southern pine was biased in the board selection (Leggate et al. 2020). The spotted gum boards were defect free feedstock destined for milled products such as flooring and decking. Seasoned boards were randomly selected from packs obtained from commercial processors of these timbers.

\section{Sample Preparation}

For each species, the boards were initially machined into pieces with dimensions of $20 \mathrm{~mm} \times 11 \mathrm{~mm} \times 450 \mathrm{~mm}(\mathrm{~W} \times \mathrm{T} \times \mathrm{L})$. All pieces were cut free of defects. These pieces were then conditioned in a constant environment chamber set at $20{ }^{\circ} \mathrm{C}$ and $65 \%$ relative humidity $(\mathrm{RH})$ (12\% equilibrium moisture content (EMC)). After conditioning, the pieces were randomly allocated to seven different mechanical surface machining preparations (Table 1).

Table 1. Mechanical Surface Machining Preparations

\begin{tabular}{|c|c|c|c|c|}
\hline $\begin{array}{l}\text { Surface } \\
\text { Machining } \\
\text { Identifier }\end{array}$ & $\begin{array}{l}\text { Surface Machining } \\
\text { Method }\end{array}$ & $\begin{array}{c}\text { Cutter } \\
\text { Specifications }\end{array}$ & $\begin{array}{l}\text { Feed, Cutter, and } \\
\text { Sanding Speeds }\end{array}$ & $\begin{array}{c}\text { Feed Per } \\
\text { Cutter (mm) }\end{array}$ \\
\hline SM1 & $\begin{array}{c}\text { Face milling } \\
\text { (fast feed speed and } \\
\text { fast cutter speed) }\end{array}$ & \begin{tabular}{|c|} 
Type: Tungsten \\
Carbide \\
Pt No: Leucodur - \\
HL 40 \\
Dim: $14 \times 14 \times 2$ mm \\
48 Cutters @ 520 \\
mm diameter (Ø) \\
\end{tabular} & $\begin{array}{c}\text { Feed rate }=45 \\
\mathrm{~m} / \mathrm{min}, \\
\text { Cutter speed }= \\
3000 \mathrm{rpm}(82 \mathrm{~m} / \mathrm{s})\end{array}$ & 0.31 \\
\hline SM2 & $\begin{array}{c}\text { Face milling } \\
\text { (fast feed speed and } \\
\text { slow cutter speed) }\end{array}$ & \begin{tabular}{|c|} 
Type: Tungsten \\
Carbide \\
Pt No: Leucodur - \\
HL 40 \\
Dim: $14 \times 14 \times 2$ mm \\
48 Cutters @ 520 \\
mm Ø
\end{tabular} & $\begin{array}{c}\text { Feed rate }=45 \\
\mathrm{~m} / \mathrm{min}, \\
\text { Cutter speed }= \\
2100 \mathrm{rpm}(57 \mathrm{~m} / \mathrm{s})\end{array}$ & 0.45 \\
\hline SM3 & $\begin{array}{c}\text { Face milling } \\
\text { (slow feed speed and } \\
\text { fast cutter speed) }\end{array}$ & \begin{tabular}{|c|} 
Type: Tungsten \\
Carbide \\
Pt No: Leucodur - \\
HL 40 \\
Dim: $14 \times 14 \times 2$ mm \\
48 Cutters @ 520 \\
mm Ø
\end{tabular} & $\begin{array}{c}\text { Feed rate }=10 \\
\mathrm{~m} / \mathrm{min}, \\
\text { Cutter speed }= \\
3000 \mathrm{rpm}(82 \mathrm{~m} / \mathrm{s})\end{array}$ & 0.07 \\
\hline
\end{tabular}




\begin{tabular}{|c|c|c|c|c|}
\hline $\begin{array}{l}\text { Surface } \\
\text { Machining } \\
\text { Identifier }\end{array}$ & $\begin{array}{l}\text { Surface Machining } \\
\text { Method }\end{array}$ & $\begin{array}{c}\text { Cutter } \\
\text { Specifications }\end{array}$ & $\begin{array}{l}\text { Feed, Cutter, and } \\
\text { Sanding Speeds }\end{array}$ & $\begin{array}{c}\text { Feed Per } \\
\text { Cutter (mm) }\end{array}$ \\
\hline SM4 & $\begin{array}{c}\text { Face milling } \\
\text { (slow feed speed and } \\
\text { slow cutter speed) }\end{array}$ & \begin{tabular}{|c|} 
Type: Tungsten \\
Carbide \\
Pt No: Leucodur - \\
HL 40 \\
Dim: $14 \times 14 \times 2$ mm \\
48 Cutters @ 520 \\
mm Ø
\end{tabular} & $\begin{array}{c}\text { Feed rate }=10 \\
\mathrm{~m} / \mathrm{min} \\
\text { Cutter speed }= \\
2100 \mathrm{rpm}(57 \mathrm{~m} / \mathrm{s})\end{array}$ & 0.10 \\
\hline SM5 & Planing & \begin{tabular}{|c|} 
High Speed Steel \\
Blade \\
$40.5^{\circ}$ Blade tip angle \\
120 mm Cutterblock \\
$\varnothing$
\end{tabular} & $\begin{array}{c}\text { Feed Rate: } 8 \mathrm{~m} / \mathrm{min} \\
\text { Cutter RPM: } 4500 \\
(28 \mathrm{~m} / \mathrm{s})\end{array}$ & 0.44 \\
\hline SM6 & $\begin{array}{l}\text { Planing and sanding } \\
\text { (40 grit) }\end{array}$ & $\begin{array}{c}\text { Belt: KLINGSPOR } \\
\text { PS } 29 \mathrm{~F} \\
\text { Grit: Aluminium } \\
\text { Oxide } \\
\text { Backing: Paper }\end{array}$ & \begin{tabular}{|} 
Planed $8 \mathrm{~m} / \mathrm{min}$ \\
feed rate + Sanding \\
using 40 grit belt \\
removing $0.3 \mathrm{~mm}$ \\
Belt Speed $=18$ \\
$\mathrm{~m} / \mathrm{min}$ \\
Feed rate $=3.5$ \\
$\mathrm{~m} / \mathrm{min}$
\end{tabular} & $-^{*}$ \\
\hline SM7 & $\begin{array}{l}\text { Planing and sanding } \\
\text { (80 grit) }\end{array}$ & $\begin{array}{c}\text { Belt: KLINGSPOR } \\
\text { PS } 29 \mathrm{~F} \\
\text { Grit: Aluminium } \\
\text { Oxide } \\
\text { Backing: Paper }\end{array}$ & \begin{tabular}{|} 
Planed $8 \mathrm{~m} / \mathrm{min}$ \\
feed rate + Sanding \\
using 80 grit belt \\
removing $0.3 \mathrm{~mm}$ \\
Belt Speed $=18$ \\
$\mathrm{~m} / \mathrm{min}$ \\
Feed rate $=3.5$ \\
$\mathrm{~m} / \mathrm{min}$
\end{tabular} & $-^{*}$ \\
\hline
\end{tabular}

Note: Due to a different machining process, feed per cutter cannot be calculated for sanding treatments

Face milling was undertaken using a Rotoles 400 D-S single side rotary planer manufactured by Ledinek (Hoče, Slovenia). This face milling approach had the rotary head and cutters positioned parallel to the machining surface with the drive shaft positioned perpendicular to the board surface (Fig. 1). The cutting direction with face milling is primarily perpendicular to the grain (Knorz et al. 2015). Conventional planing was undertaken using an SCM Group Mini Max Formula SPI thickness planer (Rimini, Italy). The conventional planer had the cutter head drive shaft positioned parallel to the board surface (Fig. 2). The cutting direction with conventional planing was primarily parallel to the grain (Knorz et al. 2015). Sanding was performed using an SCM Group SANDYA 16/S M2 135 wide belt sander (Rimini, Italy). The feed speed, cutter configuration, and cutter speed allowed the feed speed per cutter to be determined. The feed per cutter $(\mathrm{mm})$ is the theoretical length of material that passes between two cutters during machining. Feed per cutter was calculated using Eq. 1,

$$
f=\frac{v}{N n}
$$

where $v$ is the table feed speed $(\mathrm{mm} / \mathrm{min}), n$ is the number of cutters, and $N$ is the spindle speed (rpm). Within a machining type (e.g., face milling), the feed per cutter can be used as an indication of expected wood surface roughness, with increasing feed per cutter 
corresponding to increasing surface roughness (Magoss and Sitkei 2001). The feed per cutter cannot be used to directly compare expected roughness differences between face milling and planing because of differences in cutting action (perpendicular compared to parallel to grain).

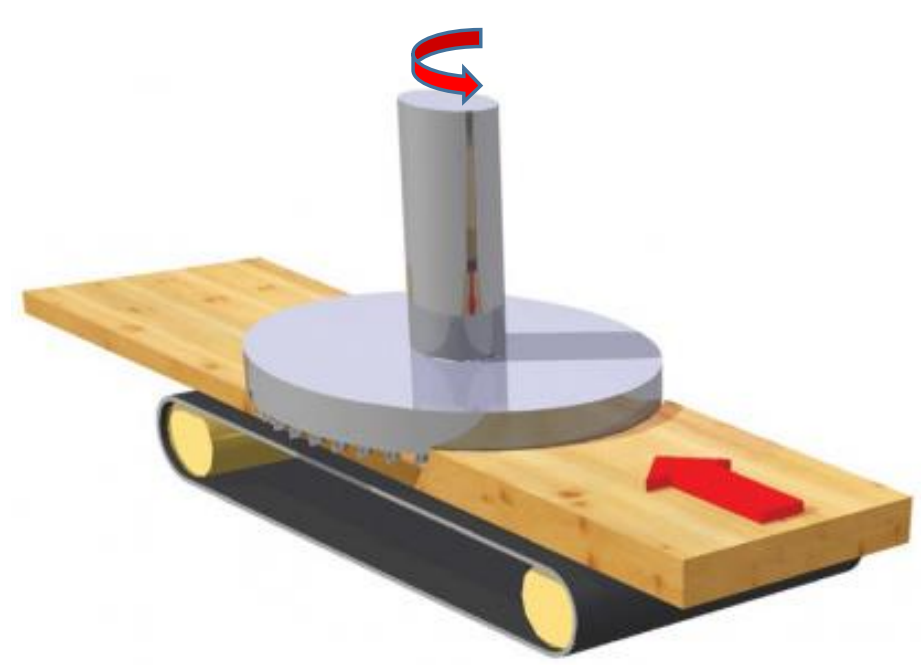

Fig. 1. Rotoles face milling approach

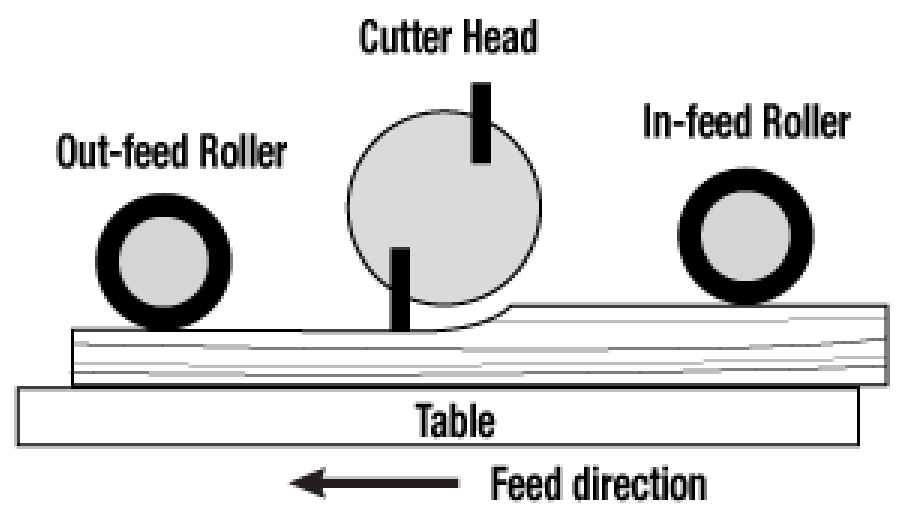

Fig. 2. Conventional planing approach

During each surface machining process described in Table 1, $1.5 \mathrm{~mm}$ was removed from the upper and lower timber surface to reduce the thickness from $11 \mathrm{~mm}$ to $8 \mathrm{~mm}$. The pieces were then docked to produce sections $(20 \mathrm{~mm} \times 8 \mathrm{~mm} \times 80 \mathrm{~mm})$. These combine as pairs for the manufacture of lap shear samples.

\section{Lap Shear Sample Manufacture}

Thirty lap shear samples were prepared for each of the seven surface machining types for each species following the principles of European Standard BS EN 205 (2016). Lap shear sample dimensions are shown in Fig. 3. 


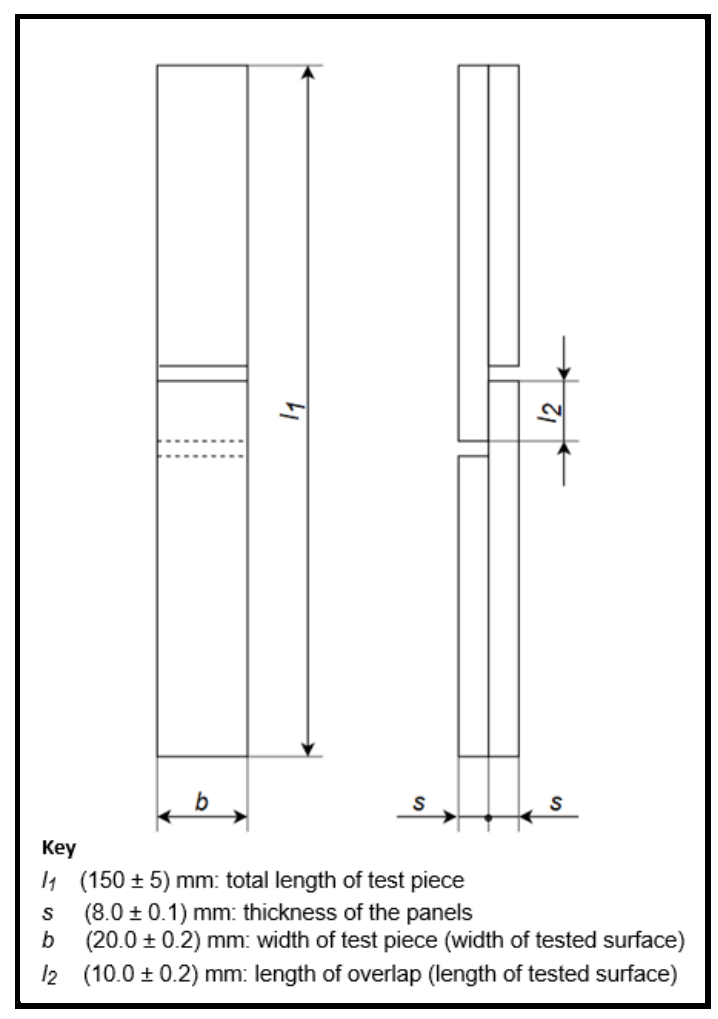

Fig. 3. Lap shear sample dimensions

Adhesive application was undertaken in a temperature-controlled room where the atmospheric conditions ranged from $21{ }^{\circ} \mathrm{C}$ to $24{ }^{\circ} \mathrm{C}$ and $35 \%$ to $58 \% \mathrm{RH}$. The application of adhesive commenced within a maximum of $20 \mathrm{~min}$ from surface machining. The adhesive bonded overlap in the lap shear samples was $10 \mathrm{~mm}$ as per Fig. 3 .

A one-component moisture-curing polyurethane (1C-PUR) adhesive (Jowat Jowapur 681.40) was used for the southern pine samples and a resorcinol formaldehyde (RF) (Jowat RF Resin 950.82 and Jowat Paraformaldehyde Hardener 950.85 mixed in a ratio of 4 parts resin to 1 part hardener) adhesive was used for the spotted gum samples. These glue types are representative of typical glues targeted commercially in structural glulam production for these species. In accordance with the technical data sheets for these adhesives, the pine lap shears had 1C-PUR applied at a spread rate of $250 \mathrm{~g}$ per square metre (gsm) and the spotted gum lap shears had RF adhesive applied at a spread rate of $350 \mathrm{gsm}$ applied to one side of the lap shear joint. Open assembly time (10 s) and closed assembly time (5 to 20 min) were the same for both southern pine and spotted gum.

The lap shear samples were pressed at $0.8 \mathrm{MPa}$ and $1 \mathrm{MPa}$ for southern pine and spotted gum, respectively. All lap shear samples remained under press pressure for a minimum of $100 \mathrm{~min}$ for the southern pine and $14 \mathrm{~h}$ for the spotted gum. After pressing, the lap shear samples were then conditioned in a constant environment chamber set at 20 ${ }^{\circ} \mathrm{C}$ and $65 \% \mathrm{RH}(12 \% \mathrm{EMC})$ for a minimum of $7 \mathrm{~d}$ before tensile shear strength testing.

\section{Tensile Shear Strength Test Method}

The determination of the tensile shear strength of lap joints was undertaken in accordance with the BS EN 205 (2016) standard. As this study aimed to compare the effects of different surface machining methods and not to quantify the actual structural strength capacity of the adhesives, BS EN 205 (2016) was deemed as suitable for use. 
Half of the lap shear samples (15 samples) for each surface machining preparation type and for each species were assigned to immediate mechanical testing, while the second half were subjected to an accelerated weathering process prior to mechanical testing. The weathering process was conducted in accordance with the AS/NZS 1328.1:1998 (2011) standard. This accelerated weathering procedure is designed to test the bond integrity of the glued element by the introduction of a moisture gradient within the element (Vella et al. 2019b). This induced an associated stress gradient with high tensile stresses perpendicular to the glue-line, which will either result in the fracture of the timber lamella or a delamination of glue-lines if the bond strength is inadequate (Vella et al. 2019b). Water impregnation of the lap shear samples was performed in a vacuum/pressure cylinder starting with total immersion of the test samples in water at $20{ }^{\circ} \mathrm{C}$ and application of a vacuum at $-78 \mathrm{kPa}$, which was held for $5 \mathrm{~min}$. A pressure cycle of $550 \mathrm{kPa}$ for $1 \mathrm{~h}$ followed. While still immersed, the vacuum/pressure cycle was repeated, resulting in a two-cycle impregnation period. All samples were dried for $21 \mathrm{~h}$ at $65^{\circ} \mathrm{C}$, a $\mathrm{RH}$ that did not exceed $15 \%$, and with an air velocity of $2.4 \mathrm{~m} / \mathrm{s}$. This water impregnation and drying cycle was performed twice, as outlined in the AS/NZS 1328.1:1998 (2011) standard.

Lap shear tensile testing was conducted using a Shimadzu AG-X universal testing machine (AG-100X; Shimadzu Corporation, Kyoto, Japan) fitted with a $100 \mathrm{kN}$ load cell with a crosshead displacement rate of $1.5 \mathrm{~mm} / \mathrm{min}$. The data was processed using Trapezium X single cycle software (Shimadzu Corporation, Version 1.5.1, Kyoto, Japan). The lap shear samples had a minimum of $40 \mathrm{~mm}$ of each end clamped into the jaws of the testing rig before being loaded in tension until failure. The maximum force applied to reach failure was recorded.

\section{Statistical Analysis}

Statistical analysis was conducted using GenStat v19 (VSN, Hemel Hempstead, United Kingdom). The data was analysed using analysis of variance (ANOVA). Fishers Protected Least Significant Differences testing was completed to compare means when ANOVA showed significance in a factor.

\section{RESULTS AND DISCUSSION}

\section{Southern Pine}

Tensile shear strength

Tensile shear strength results for southern pine are shown in Table 2, and Figs. 4 and 5 for non-weathered and weathered lap shear samples, respectively. Because planing is the most common pre-gluing surface machining method internationally (Knorz et al. 2015), the results are expressed as a percentage of the mean values for the planing surface machining method (SM5).

For the non-weathered samples of southern pine, the differences in tensile shear strength between surface machining groups were not statistically significant. However, the highest mean tensile shear strength of lap shear samples was achieved with face milling treatments SM1, SM2, and SM4, with the face milling fast feed speed/slow cutter speed (SM2) producing the highest mean tensile shear strength result and less variation compared to the other face milling methods. 
Table 2. Summary of Tensile Shear Strength Results for Lap Shear Samples (Southern Pine)

\begin{tabular}{|c|c|c|}
\hline \multirow{2}{*}{$\begin{array}{c}\text { Surface } \\
\text { Machining } \\
\text { Method }\end{array}$} & \multicolumn{2}{|c|}{$\begin{array}{c}\text { Mean Tensile Shear Strength as a } \\
\text { \% of SM5 Mean Tensile Shear Strength }\end{array}$} \\
\cline { 2 - 3 } & Non-weathered & Weathered \\
\hline SM1 & $111(23) \mathrm{a}$ & $120(11) \mathrm{ab}$ \\
\hline SM2 & $118(15) \mathrm{a}$ & $125(16) \mathrm{ab}$ \\
\hline SM3 & $98(29) \mathrm{a}$ & $100(35) \mathrm{c}$ \\
\hline SM4 & $111(19) \mathrm{a}$ & $118(9) \mathrm{ab}$ \\
\hline SM5 & $100(12) \mathrm{a}$ & $100(13) \mathrm{c}$ \\
\hline SM6 & $103(13) \mathrm{a}$ & $113(12) \mathrm{b}$ \\
\hline SM7 & $109(14) \mathrm{a}$ & $129(9) \mathrm{a}$ \\
\hline
\end{tabular}

Notes: Standard deviation shown in parenthesis; means followed by the same letter in the same column are not significantly different $(0.05)$

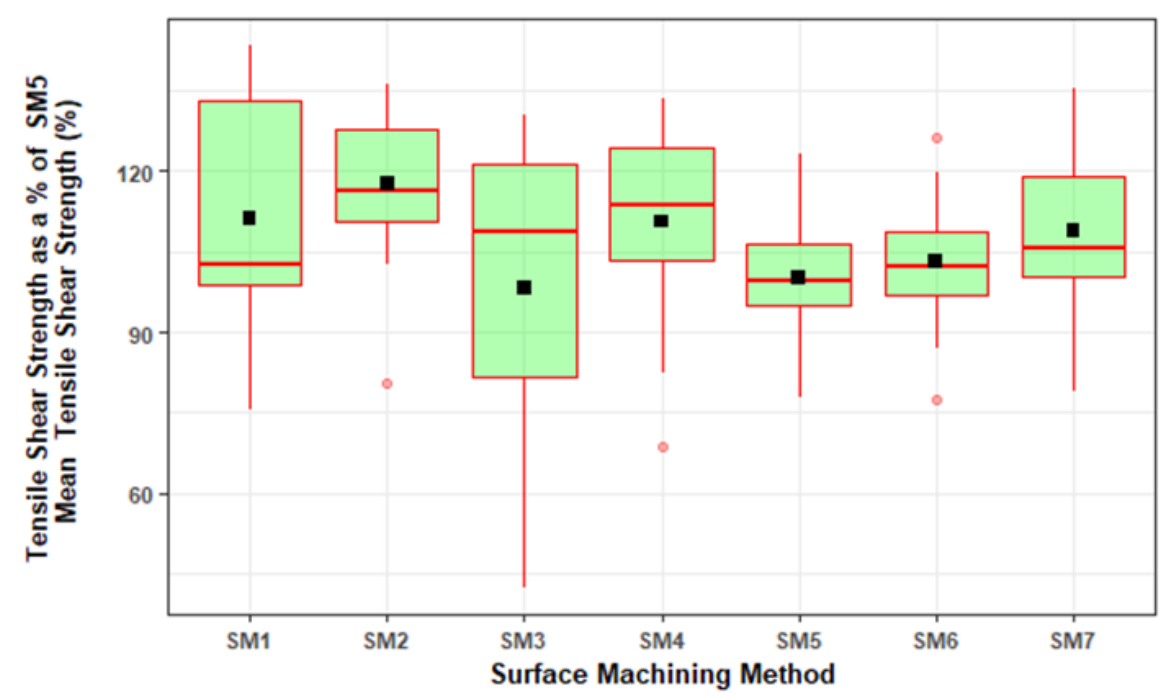

Fig. 4. Tensile shear strength results for non-weathered samples of southern pine

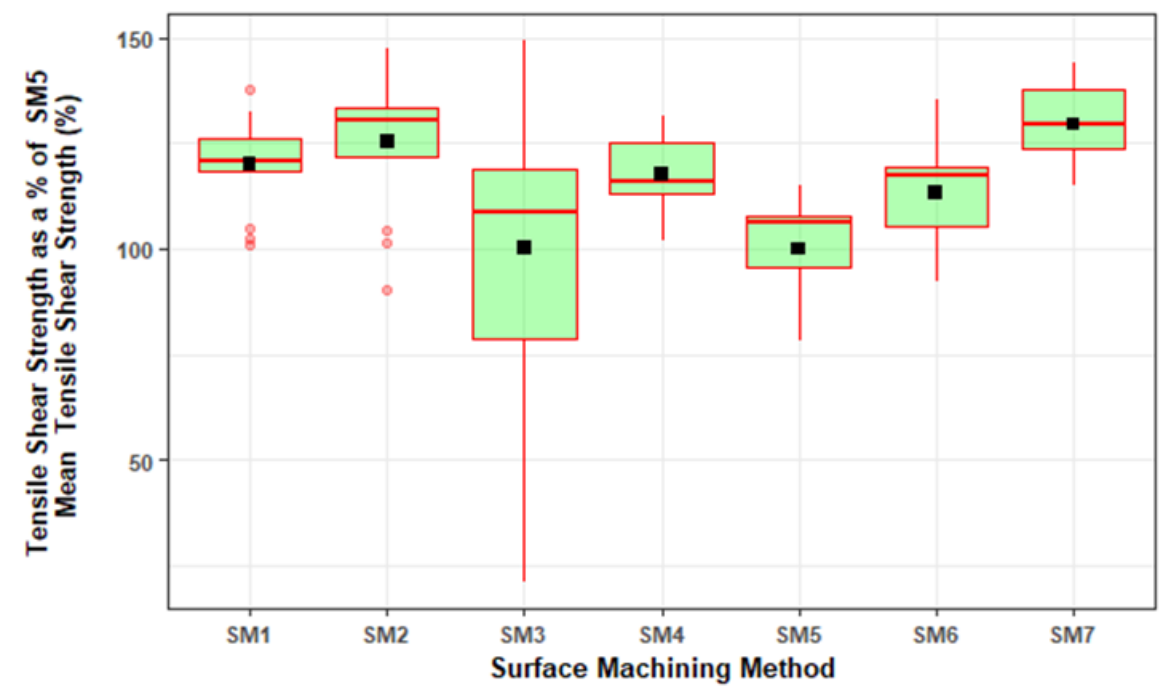

Fig. 5. Tensile shear strength results for weathered samples of southern pine 
The lowest mean tensile shear strength resulted from the face milling slow feed speed/fast cutter speed treatment (SM3), which was negatively impacted by the wide variation and several very low results. Despite the low mean result, the median value for SM3 was higher than all other surface machining groups except for SM2 and SM4. The median for the four face milling groups (SM1-4) was higher than the planing (SM5) and sanding post-planing treatments (SM6 and SM7). The planing treatment (SM5) recorded the lowest median value for tensile shear strength.

For the weathered samples of southern pine, the surface machining method had a significant effect on tensile shear strength $(\mathrm{p}<0.001)$. The highest mean tensile shear strength of lap shear samples was achieved with 80 grit sanding post-planing (SM7), followed by face milling fast feed speed/slow cutter speed (SM2). Similar to the nonweathered sample tests, the planing treatment (SM5) recorded the lowest median value for tensile shear strength for weathered sample tests, whereas the highest median value resulted from face milling fast feed speed/slow cutter speed (SM2). The SM3 treatment recorded the second lowest mean value and was characterized by a much greater variation in results compared to the other surface machining treatments. Apart from the SM3 treatment, all face milling and sanding post-planing treatments resulted in significantly higher mean tensile shear strength compared to planing.

In both non-weathered and weathered tests for southern pine, the planing surface machining method, which is currently the most common pre-gluing surfacing method used by industry internationally, generally produced lower mean lap shear tensile strength results. The face milling (apart from the SM3 group) and sanding post-planing treatments produced higher mean tensile shear strengths in both test configurations. Other studies have reported better bond strength results with face milling or sanding compared to planing on different timbers (Kuljich et al. 2013; Kläusler et al. 2014; Knorz et al. 2015).

Differences in results between the surface machining methods can most likely be explained by the resulting wood surface roughness, fibrillation (packets of micro-fibrils torn out from cell walls (De Moura et al. 2010), and sub-surface cell damage, which influence the wettability, permeability, glue penetration, glue-line thickness, and bond integrity. Rankings for tensile shear strength for the four face milling treatments were generally aligned to the feed per cutter ranking (Table 1). As feed speed increases, chip size and surface roughness increases, whereas as cutter speed increases, chip size and surface roughness decreases (Magoss and Sitkei 2001; Guo et al. 2015; Vančo et al. 2017). The SM2 had the largest feed per cutter (SM2 with $0.45 \mathrm{~mm}$ ) from the face milling treatments; therefore, it was expected to produce the highest surface roughness, and this treatment resulted in the highest mean tensile shear strength. In contrast, slow feed speed/fast cutter speed (SM3) face milling would be expected to produce the lowest surface roughness (i.e., smoothest finish), and it resulted in the lowest mean tensile shear strength compared to the other face milling treatments tested. The differences between the 40 grit and 80 grit sanding post-planing treatments in tensile shear strength are explained by differences in the magnitude of roughness, fibrillation, and sub-surface damage results. Even though the 40 grit sanding post-planing would be expected to produce higher roughness than 80 grit sanding, it potentially results in a lower amount of surface fibrillation and a higher amount of sub-surface cellular damage.

Leggate et al. (2020) evaluated the effects of the same seven surface machining treatments on the wettability of southern pine, showing that planing resulted in the lowest wettability, whereas the face milling treatments and sanding treatments post-planing resulted in higher wettability. This corresponds closely with the tensile shear strength 
results. Factors likely to be contributing to both the wettability and tensile shear strength results are the effects of the surface machining process on surface roughness, fibrillation, and on wood anatomy, such as surface and sub-surface cellular damage. Face milling and sanding treatments have been shown, in other studies using different species, to result in higher roughness and fibrillation and differences in the levels of sub-surface cell damage compared to planing (Knorz et al. 2015). Higher wood surface roughness and fibrillation have been shown to increase the wood wettability and bonding strength through the facilitation of adhesive spreading by improved capillarity, an increased surface area for mechanical adhesion, and an increased exposure of hydrophilic sites for the adhesive to bond to (Hernández and Cool 2008a; Santoni and Pizzo 2011; Kläusler et al. 2014; Knorz et al. 2015; Qin et al. 2014; Jankowska et al. 2018). Fibrillation is reported to improve wood adhesive bond performance by fortifying the adhesive layer and creating a more homogenous strain dissipation in the glue-line (Knorz et al. 2015). Additionally, face milling is reported to produce better results for wood adhesion compared to conventional planing because the face milling cutting action (perpendicular to the grain) generates lower cutting forces and consequently lower sub-surface damage of the wood structure compared to conventional planing (cutting direction parallel to the grain) (Santoni and Pizzo 2011; Kläusler et al. 2014; Knorz et al. 2015). The perpendicular-to-the-grain cutting action of face milling results in lower cutting forces than a machining process parallel to the grain because of the lower strength of the wood in the transverse direction (De Moura et al. 2010; Knorz et al. 2015). Sub-surface cell damage results in the formation of a mechanically weak boundary layer that causes poor bond performance and failure (De Moura et al. 2010; Kläusler et al. 2014). Follrich et al. (2010) reported increased tensile strength of bonds with increased surface roughness, although the findings regarding the influence of roughness on bonding performance are not fully consistent (Kläusler et al. 2014) with excessive roughness, sometimes resulting in decreased bond strength if it is associated with crushed and damaged cells becoming prevalent that can lead to a mechanically weak boundary layer and impeded adhesive penetration (Knorz et al. 2015).

Wood permeability is one of the main controlling factors influencing the depth of adhesive penetration (Burch 2015; Hovanec 2015; Kumar and Pizzi 2019; Leggate et al. 2020). Leggate et al. (2020) evaluated the effects of the same seven surface machining treatments on the permeability of southern pine, showing that planing resulted in the highest permeability, whereas the sanding treatments post-planing resulted in the lowest permeability. The permeability results did not match the wettability results in the previous study, and no relationship was found between permeability and tensile shear strength results in this study. Further investigations of the influence of permeability on adhesive bond performance are warranted to better appreciate the interaction with other important adhesion parameters, such as glue penetration and glue line thickness. These studies should investigate permeability at shallower depths from the surface compared to the current study, to relate wood wettability, adhesive penetration, and bond performance.

Table 2 shows that the accelerated weathering test greatly increased the differences in mean tensile shear strength between the planing (SM5) and most other surface machining treatments. This reflects the intent of the accelerated weathering test, which is designed to test the bond integrity of the glued element by the introduction of a moisture gradient and associated stress gradient within the element (Vella et al. 2019b). The accelerated weathering test for tensile shear strength highlighted the benefits of face milling fast feed speed/slow cutter speed (SM2) and sanding treatment-post planing (SM7), especially compared to planing (SM5) in bond durability. 


\section{Spotted Gum}

Tensile shear strength

Tensile shear strength results for spotted gum are shown in Table 3, and Figs. 6 and 7 for non-weathered and weathered samples, respectively. Like above, the results are expressed as a percentage of the mean values for the planing surface machining method (SM5).

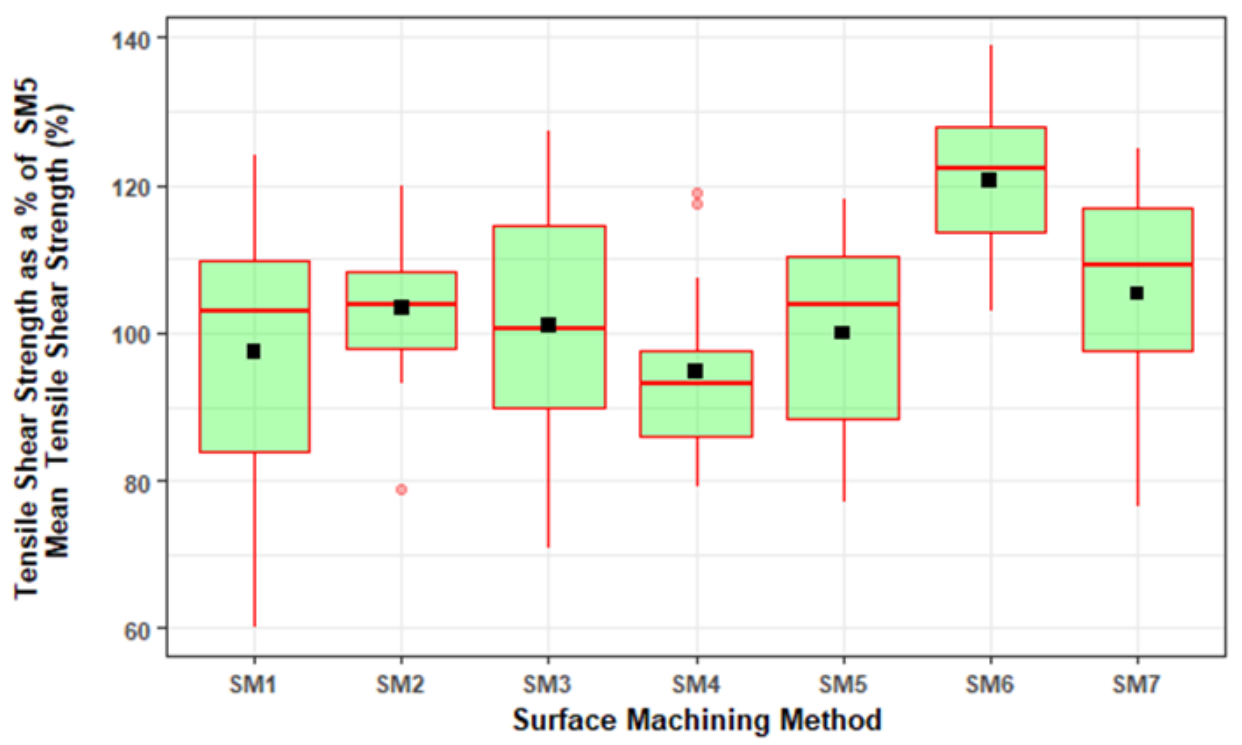

Fig. 6. Tensile shear strength results for non-weathered samples of spotted gum

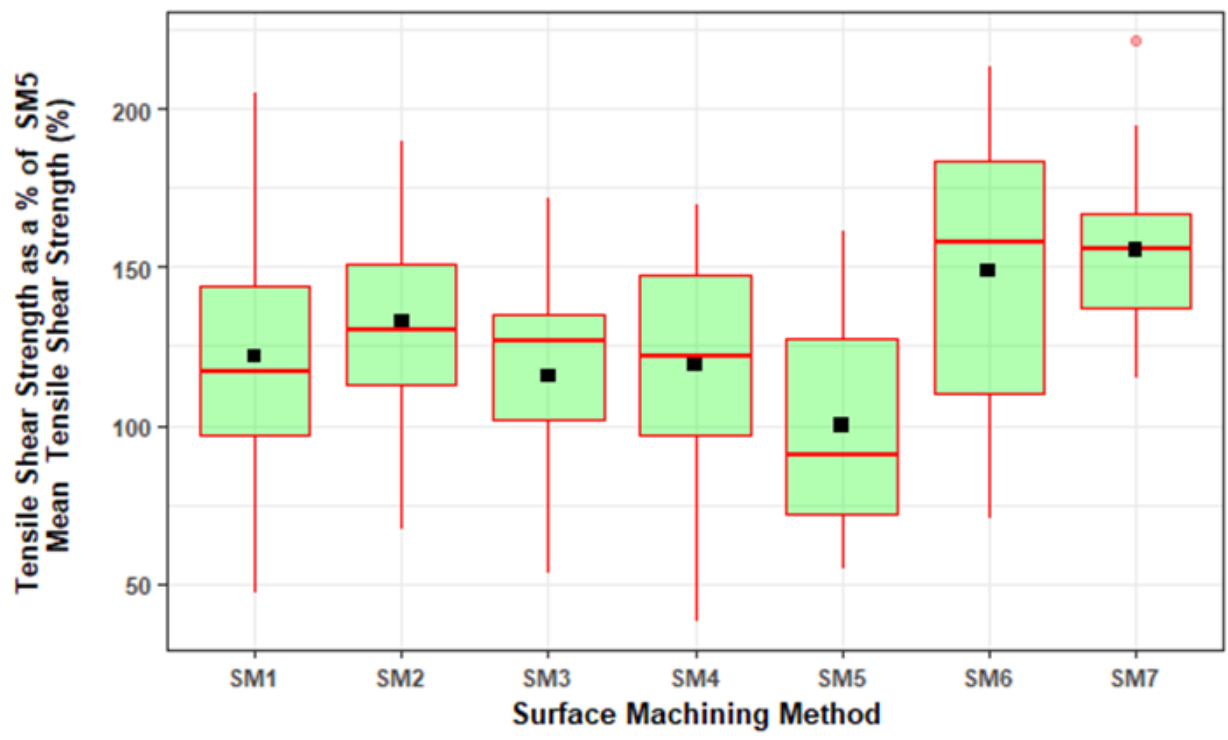

Fig. 7. Tensile shear strength results for weathered samples of spotted gum

Surface machining method had a significant effect on tensile shear strength for nonweathered sample tests $(\mathrm{p}<0.001)$ for spotted gum. The 40 grit sanding treatment postplaning (SM6) produced a mean tensile shear strength significantly higher than all other surface machining treatments (Table 3). There was no significant difference between the remaining treatments. The other sanding post-planing treatment (SM7) had the second 
highest mean tensile shear strength followed by the face milling fast feed speed/slow cutter speed (SM2) treatment. The SM2 treatment produced the least variation. The lowest mean tensile shear strength resulted from the fast feed speed/fast cutter speed and slow feed speed/slow cutter speed face milling treatments (SM1 and SM4). However, these results were not significantly different to the other treatments, except for the SM6 treatment.

Table 3. Summary of Tensile Shear Strength for Lap Shear Samples (Spotted Gum)

\begin{tabular}{|c|c|c|}
\hline \multirow{2}{*}{$\begin{array}{c}\text { Surface } \\
\text { Machining } \\
\text { Method }\end{array}$} & \multicolumn{2}{|c|}{$\begin{array}{c}\text { Mean Tensile Shear Strength as a } \\
\text { \% of SM5 Mean Tensile Shear Strength }\end{array}$} \\
\cline { 2 - 3 } & Non-weathered & Weathered \\
\hline SM1 & $97(20) \mathrm{a}$ & $122(46) \mathrm{bcd}$ \\
\hline SM2 & $103(10) \mathrm{a}$ & $133(35) \mathrm{abc}$ \\
\hline SM3 & $101(17) \mathrm{a}$ & $116(38) \mathrm{cd}$ \\
\hline SM4 & $95(12) \mathrm{a}$ & $119(95) \mathrm{cd}$ \\
\hline SM5 & $100(14) \mathrm{a}$ & $100(34) \mathrm{d}$ \\
\hline SM6 & $121(12) \mathrm{b}$ & $149(44) \mathrm{ab}$ \\
\hline SM7 & $105(15) \mathrm{a}$ & $155(30) \mathrm{a}$ \\
\hline
\end{tabular}

Notes: Standard deviation shown in parenthesis; means followed by the same letter in the same column are not significantly different $(0.05)$

For the weathered spotted gum samples, the surface machining method had a significant effect on tensile shear strength $(\mathrm{p}<0.01)$. The highest mean tensile shear strength results matched closely the results for non-weathered samples, with the highest mean tensile shear strength achieved by the two sanding post-planing treatments (SM6 and SM7), followed by the face milling fast feed speed/slow cutter speed (SM2) treatment. The lowest mean tensile shear strength resulted from planing (SM5), followed by the slow feed speed/fast cutter speed face milling (SM3) treatment. The tensile shear strength of the planing group was significantly lower than that of the two sanding post-planing (SM6 and SM7) and face milling fast feed speed/slow cutter speed (SM2) treatments.

Similar to the southern pine analysis discussed above, observed differences between the surface machining methods can most likely be explained by the different effects of these treatments on roughness, fibrillation, and wood anatomy (e.g., sub-surface cell damage), which influences the wettability, permeability, glue penetration, glue-line thickness, and bond integrity. Within the face-milling treatments, the rankings for weathered sample tensile shear strength are the same as that of southern pine discussed above. The expected rankings for roughness based on the feed per cutter results shown in Table 1.

Leggate et al. (2020) evaluated the effects of the same seven surface machining treatments on the wettability of spotted gum reporting that planing resulted in the lowest wettability, whereas sanding (80 grit) post-planing (SM7), slow feed speed/fast cutter speed face milling (SM3), and fast feed speed/slow cutter speed face milling (SM2) resulted in higher wettability. Except for the result for the slow feed speed/fast cutter speed face milling (SM3), the wettability performance corresponded well with the tensile shear strength results for weathered samples. As discussed for the southern pine results, particular face milling and sanding treatments have been shown in other studies using different species to result in higher surface roughness, increased fibrillation, and 
differences in subsurface damage to the wood structure compared to planing (e.g., Knorz et al. 2015), resulting in improved bond performance. This is likely an explanation for the observations made during this study.

Leggate et al. (2020) additionally evaluated the effects of the same seven surface machining treatments on the permeability of spotted gum, showing that planing (SM5) resulted in the lowest permeability, whereas the face milling with slow feed speed/slow cutter speed (SM4) resulted in the highest permeability. No clear relationship was found between permeability and tensile shear strength results in this study. However, the surface machining method that produced the lowest permeability and wettability (planing- SM5), also resulted in the lowest mean tensile shear strength in weathered samples. As discussed above for southern pine, further investigations of the influence of permeability on adhesive bond performance are warranted to better appreciate the interaction with other important adhesion parameters, such as glue penetration and glue line thickness. These studies should investigate permeability at shallower depths from the surface compared to the current study, to relate wood wettability, adhesive penetration, and bond performance.

Table 3 shows that the accelerated weathering test greatly increased the differences in tensile shear strength between the planing (SM5) and all other surface machining treatments. This was also observed for the southern pine. The accelerated weathering test for tensile shear strength highlighted the benefits of face milling fast feed speed/slow cutter speed (SM2) and sanding treatments-post planing compared to planing in improving adhesive bond performance. Additionally, the variation in tensile shear strength results within surface machining treatment groups increased because of the weathering procedure.

\section{CONCLUSIONS}

1. The pre-gluing surface machining method influenced the tensile shear strength of southern pine and spotted gum lap shear samples. The tensile shear strength results for both species showed strong relationships with wettability but not with permeability.

2. For southern pine, the influence of surface machining method on tensile shear strength of lap shear samples varied with non-weathered and weathered tests, although differences between surface machining methods were only significant for weathered tests. However, when considering results across both test types, face milling with fast feed speed and slow cutter speed (SM2) produced the best overall mean tensile shear strength results. For weathered tests only, sanding (80 grit) post-planing (SM7) resulted in the highest mean tensile shear strength. Planing (SM5) generally produced the lowest tensile shear strength.

3. For spotted gum, surface machining method had a significant effect on tensile shear strength for non-weathered and weathered tests. The influence of surface machining method on tensile shear strength of lap shear samples was reasonably consistent across non-weathered and weathered tests, with the highest mean tensile shear strength being achieved with sanding treatments (40 grit and 80 grit) post-planing (SM6 and SM7) and face milling with fast feed speed and slow cutter speed (SM2). For weathered tests, planing produced the lowest mean tensile shear strength compared to the other surface machining methods tested. 
4. The results from the testing of key parameters known to influence bond performance demonstrates that the selection of surface machining method prior to gluing is likely to influence the adhesive bond-performance of engineered wood products when manufactured from either southern pine or spotted gum. Face milling configurations that target larger feed-per-cutter settings and sanding treatments post-planing provide better wood adhesion conditions compared to planing. Optimizing of manufacturing protocols (e.g., adhesive spread rates, open and closed assembly times, and press pressure conditions) with the selected board surface machining method is necessary to ensure the improvements in potential bond performance can be realized.

\section{ACKNOWLEDGMENTS}

The authors are particularly grateful for the technical support of Mr. Eric Littee, Mr. Dan Field, and Mr. Thomas Davies with the preparation, processing, and testing of wood samples. Mr. Bob Mayer is acknowledged for assistance with statistical analysis. The support provided by the Queensland Government, Department of Agriculture and Fisheries (DAF) through the provision of the unique facilities located at the Salisbury Research Facility is acknowledged as critical to facilitate studies of this nature. The authors are very grateful to Mr. Rod Vella from Jowat Universal Adhesives Australia Pty Ltd. for the provision of the adhesives used in the study.

\section{REFERENCES}

AS/NZS 1328.1:1998 (2011). "Glued laminated structural timber. Part 1: Performance requirements and minimum production requirements," Standards Australia, Sydney, Australia.

AS/NZS 1720.2 (2006). “Timber structure, Part 2: Timber properties,” Standards Australia, Sydney, Australia.

AS/NZS 1748.1 (2011). "Timber - Solid - Stress-graded for structural purposes General requirements," Standards Australia, Sydney, Australia.

Aydin, İ. (2004). "Activation of wood surfaces for glue bonds by mechanical pretreatment and its effects on some properties of veneer surfaces and plywood panels," Applied Surface Science 233(1-4), 268-274. DOI: 10.1016/j.apsusc.2004.03.230

BS EN 205 (2016). “Adhesives. Wood adhesives for non-structural applications. Determination of tensile shear strength of lap joints," British Standards Institution, London, United Kingdom.

Burch, C. P. (2015). Adhesion Fundamentals in Spotted Gum (Corymbia spp.), Master's Thesis, Virginia Polytechnic Institute and State University, Blacksburg, VA, USA.

De Moura, L. F., Cool, J., and Hernàndez, R. E. (2010). “Anatomical evaluation of wood surfaces produced by oblique cutting and face milling," IAWA Journal 31(1), 77-88. DOI: $10.1163 / 22941932-90000007$

Follrich, J., Vay, O., Veigel, S., and Müller, U. (2010). "Bond strength of end-grain joints and its dependence on surface roughness and adhesive spread," Journal of Wood Science 56, 429-434. DOI: 10.1007/s10086-010-1118-1

Guo, X., Li, R., Cao, P., Ekevad, M., Cristóvão, L., Marklund, B., and Grönlund, A. (2015). "Effect of average chip thickness and cutting speed on cutting forces and 
surface roughness during peripheral up milling of wood flour/polyvinyl chloride composite," Wood Research 60(1), 147-156.

Hernández, R. E., and Cool, J. (2008a). "Effects of cutting parameters on surface quality of paper birch wood machined across the grain with two planing techniques," Holz als Roh - und Werkstoff 66, 147-154. DOI: 10.1007/s00107-007-0222-4

Hernández, R. E., and Cool, J. (2008b). "Evaluation of three surfacing methods on paper birch wood in relation to water and solvent-borne coating performance," Wood Fiber Science 40(3), 459-469.

Hovanec, D. (2015). Effect of Wood Characteristics on Adhesive Bond Quality of YellowPoplar for Use in Cross-laminated Timbers, Master's Thesis, West Virginia University, Morgantown, WV, USA.

Jankowska, A., Zbiec, M., Kozakiewicz, P., Koczan, G., Olenska, S., and Beer, P. (2018). "The wettability and surface free energy of sawn, sliced and sanded European oak wood," Maderas. Ciencia y Technologia 20(3), 443-454. DOI: 10.4067/S0718221X2018005031401

Kläusler, O., Rehm, K., Elstermann, F., and Niemz, P. (2014). "Influence of wood machining on tensile shear strength and wood failure percentage of one-component polyurethane bonded wooden joints after wetting," International Wood Products Journal 5(1), 18-26. DOI: 10.1179/204264531Y.0000000039

Knorz, M., Neuhaeuser, E., Torno, S., and Van de Kuilen, J. W. (2015). "Influence of surface preparation methods on moisture-related performance of structural hardwoodadhesive bonds," International Journal of Adhesion and Adhesives 57(2015), 40-48. DOI: $10.1016 /$ j.ijadhadh.2014.10.003

Kuljich, S., Cool, J., and Hernández, R. E. (2013). "Evaluation of two surfacing methods on black spruce wood in relation to gluing performance," Journal of Wood Science 59, 185-194. DOI: 10.1007/s10086-012-1318-y

Kumar, R. N., and Pizzi, A. (2019). Adhesives for Wood and Lignocellulosic Materials, John Wiley \& Sons Inc., Hoboken, NJ, USA.

Leggate, W. (2018). Improving the Durability Performance of Engineered Wood Products: A Study Tour of Europe and North America (Gottstein Fellowship Report), Gottstein Trust, Melbourne, Australia.

Leggate, W., McGavin, R., Miao, C., Outhwaite, A., Chandra, K., Dorries, J., Kumar, C., and Knackstedt (2020). "The influence of mechanical surface preparation methods on southern pine and spotted gum wood properties: Wettability and permeability," BioResources 15(4), 8554-8576.

Magoss, E., and Sitkei, G. (2001). "Fundamental relationships of wood surface roughness at milling operations," Proceedings of the $15^{\text {th }}$ International Wood Machining Seminar 2001, 437-446.

Market Research Future (2020). "Engineered wood market research report - forecast to 2023," (https://www.marketresearchfuture.com/reports/engineered-wood-market4791), Accessed 24 July 2020.

Qin, Z., Zhang, Q., Gao, Q., Zhang, S., and Li, J. (2014). "Wettability of sanded and aged fast-growing poplar wood surfaces: I. Surface free energy," BioResources 9(4), 71767188. DOI: 10.15376/biores.9.4.7176-7188

Santoni, I., and Pizzo, B. (2011). "Effect of surface conditions related to machining and air exposure on wettability of different Mediterranean wood species," International Journal of Adhesion and Adhesives 31(7), 743-753. DOI:

10.1016/j.ijadhadh.2011.07.002 
Sernek, M. (2002). Comparative Analysis of Inactivated Wood Surfaces, Ph.D.

Dissertation, Faculty of the Virginia Polytechnic Institute and State University, Blacksburg, VA, USA.

Vančo, M., Mazán, A., Barcík, S., Rajko, L., Koleda, P., Vyhnálikova, Z., and Safin, R. R. (2017). "Impact of selected technological, technical, and material factors on the quality of machined surface at face milling of thermally modified pine wood," BioResources 12(3), 5140-5154. DOI: 10.1376/biores.12.3.5140-5154

Vella, R., Heitzmann, M. T., and Redman, A. (2019a). "Improving the adhesion of highdensity softwoods with isocyanate based adhesives through surface incision," BioResources 14(4), 7751-7762. DOI: 10.15376/biores.14.4.7751-7762

Vella, R., Heitzmann, M. T., Redman, A., and Bailleres, H. (2019b). "Comparison of test methods for the determination of delamination in glued laminated timber," BioResources 14(4), 7920-7934. DOI: 10.15376/biores.14.4.7920-7934

Vella, R. (2020). Improving the Adhesion of High-density Softwoods with Isocyanate Based Adhesives, Master's Thesis, University of Queensland, Brisbane, QLD, Australia.

Vick, C. B. (1999). "Adhesive bonding of wood materials," in: Wood Handbook: Wood as an Engineering Material, USDA Forest Service, Forest Products Laboratory, Madison, WI, USA.

Article submitted: August 25, 2020; Peer review completed: Oct 21, 2020; Revised version received and accepted: November 2, 2020; Published: November 6, 2020.

DOI: 10.15376/biores.16.1.46-61 